\title{
Evaporation and wettability of fungicide spray, with or without adjuvant, on leaves of vegetables
}

\author{
Laís MB Precipito; Gustavo Dario; João V Oliveira; Rone B Oliveira ${ }^{1}$
}

${ }^{1}$ Universidade Estadual do Norte do Paraná (UENP), Bandeirantes-PR, Brazil; laisbonadio@gmail.com; gdgustavodario@gmail; joaovictordeoliveira@hotmail.com; rone@uenp.edu.br

\begin{abstract}
On tomato, cucumber and bell pepper cultivation, commonly large quantities of plant-protection products are applied, to control pests and diseases, as a way to guarantee better productivity and final product quality. The knowledge of spreading and evaporation time of spray droplets is fundamental to understand the interaction between fungicides and target surface for proper distribution of this fungicide. This study was installed to determine the wetting area and droplet evaporation of sprays containing the fungicide Cabrio Top, with or without adjuvant Nimbus ${ }^{\circledR}$, deposited on leaves and artificial surfaces (glass slide). A system was used which analyzes images composed of a droplet generator, a stereoscope camera for capturing images and a climatic chamber for controlling temperature and relative air humidity. Droplets of $600 \mu \mathrm{m}$ in diameter containing spray solution were deposited on leaf surfaces and on glass slide and sequential images were used to quantify the wetting area and the evaporation time. The spray solution and the target surface are determinant for wetness and droplet evaporation after deposition. Evaporation time and surface tension were inversely proportional to the wetting areas. Addition of adjuvant $\operatorname{Nimbus}^{\circledR}(0.5 \%, \mathrm{v} / \mathrm{v})$ reduced the surface tension and provided an increase in the wetting surface area, except on tomato leaves which had shown low wetting capacity in both fungicide solutions applied.
\end{abstract}

Keywords: Vegetables, application technology, greenhouse, image analysis, spray droplets.

\section{RESUMO}

Evaporação e capacidade de molhamento de caldas fungicida com e sem adjuvantes em folhas de hortaliças

Nos cultivos de tomate, pepino e pimentão é comum a utilização de grande número de aplicações de produtos fitossanitários para o controle de pragas e doenças como forma de garantir melhor produtividade e qualidade do produto final. O conhecimento do espalhamento e do tempo de evaporação de gotas de pulverização é fundamental para entender a interação entre a calda de fungicida e a superfície alvo para adequada distribuição do fungicida. O objetivo desta pesquisa foi determinar a área de molhamento e o tempo de evaporação de gotas contendo o fungicida Cabrio Top sem e com o adjuvante Nimbus ${ }^{\circledR}$ depositadas em superfícies foliares das culturas de tomate, pimentão, pepino e superfície artificial (lâmina de vidro). Utilizou-se um sistema de análises por imagens, gerador de gotas, um estereoscópio com câmera para captura de imagens e uma câmara climática de controle de temperatura e umidade relativa do ar. Gotas de $600 \mu \mathrm{m}$ de diâmetro contendo as caldas de pulverização foram depositadas nas superfícies foliares e lâmina de vidro e as imagens sequenciais foram usadas para quantificar a área de molhamento e o tempo de evaporação. A calda de pulverização e a superfície alvo são determinantes no molhamento e na evaporação das gotas após a deposição. O tempo de evaporação e a tensão superficial apresentam relação negativa com o molhamento. A adição do adjuvante Nimbus ${ }^{\mathbb{R}}$ $(0,5 \%, v / v)$ reduziu a tensão superficial e proporcionou aumento da área de molhamento das superfícies, com exceção em folhas de tomateiro, que apresentaram baixa capacidade de molhamento em ambas as caldas.

Palavras-chave: Hortaliças, tecnologia de aplicação, cultivo protegido, análise por imagem, gotas de pulverização.

Received on March 29, 2017; accepted on April 17, 2018

$\mathrm{T}_{\mathrm{p}}$ omato (Solanum lycopersicum), bell pepper (Capsicum annuum) and cucumber (Cucumis sativus) are among the main vegetables grown in protected environment. Cultivation of vegetables is difficult due to pests and diseases which occur during the vegetative cycle, which can cause total production loss, being necessary to apply phytosanitary products. Thus, knowing how these products act after deposition on the target is fundamental to ensure effective application.

Spray efficiency is directly related to spreading and evaporation of deposited droplets, which can be reduced if the active ingredient is not spread evenly over the target (Xu et al., 2010). Differences on external characteristics of the foliar surfaces and intrinsic properties of the spray solution influence wetting and droplet evaporation time
(Yu et al., 2009). Adding adjuvants to plant protection product may alter the spray droplet distribution onto the target (Hunsche \& Noga, 2012). Using mineral oil as an adjuvant may reduce surface tension, favor spreading and absorption of droplets on the leaf surface (Mendonça et al., 2007).

Spreading and evaporation of fungicides on leaf surfaces are poorly studied and sequential analysis of droplet 
images can contribute to understand interaction between fungicide and adjuvant on leaf surfaces and optimize the use of phytosanitary products under field conditions or greenhouse. Therefore, the aim of this study was to determine the wetting area and the evaporation time of droplets containing fungicide Cabrio Top with and without adjuvant Nimbus ${ }^{\circledR}$, deposited on leaf surfaces of tomato, bell pepper and cucumber crops, in comparison with an artificial surface (glass slide).

\section{MATERIAL AND METHODS}

The authors evaluated the wetting area and droplet evaporation time with and without fungicide and with adjuvants on the leaves of tomato, cucumber, bell pepper and glass slides under controlled conditions of temperature and relative humidity. The surface tension of applied solutions was determined through the method proposed by Mendonça et al. (1999), consisting of weighing droplets of a liquid formed at the end of a burette. Fungicide Cabrio Top (methyram + pyraclostrobin), from the chemical group alkylenebis and strobilurin, and the adjuvant Nimbus ${ }^{\circledR}$ (mineral oil) were used.

The experimental design was entirely randomized, in $2 \times 4$ factorial scheme, consisting of two spray solutions [fungicide Cabrio Top $(0.2 \%, \mathrm{~m} / \mathrm{v})$ with and without adjuvant $\mathrm{Nimbus}^{\circledR}(0.5 \%$, $\mathrm{v} / \mathrm{v})$ ], and four kinds of surfaces [three natural (leaves of tomato, cucumber and green pepper) and one artificial or hydrophilic surface (glass slide)], with five replicates.

The sprays were prepared with distilled water in 1-L volumetric flasks. Plants were grown in commercial production system and collected in greenhouses in the municipality of Bandeirantes-PR on the same day the researches were performed. Leaves of long shelf-life tomato 'Pizzadoro', red bell pepper 'Pampa' and "caipira" cucumber 'Campeiro', were used. Plants were in vegetative stage.

In order to determine wetting area and evaporation time, the authors used an automatic system with controlled temperature and relative humidity, which also generates droplets and captures sequential images, demonstrated by Oliveira et al. (2015). Trial was performed at $30 \pm 1.5^{\circ} \mathrm{C}$ and $60 \%$ relative humidity $( \pm 3 \%)$. Relative humidity was altered using humidificationdehumidification process and the temperature was changed using an air conditioned and an infrared heater, interconnected to temperature and humidity sensors with high accuracy and reproducibility using a programmable logic controller (PLC). Sequential images of the droplets deposited on different surfaces were performed by a stereoscope equipped with a highdefinition digital camera and software for capture. Droplets with $600 \pm 25 \mu \mathrm{m}$ diameter were deposited; these droplets were formed using a droplet generator which contemplates a quantity of liquid spray regulator based on the time regulation, air pressure of the dispensed fluid and vacuum (ModelUltimus V, EFD Inc; East Providence, RI).

For calibration and standardization of droplet size, twenty droplets were deposited on silk threads attached to a support, which allows these droplets to remain in spherical shape in order to measure their diameter. Droplet ejection interval, pressure and droplet generator vacuum were altered until the droplets formed a $600 \mu \mathrm{m}$ diameter. This calibration was done for each solution to analyze all droplets of the same size.

Droplets on the surface were visualized with the aid of a stereoscope (zoom 1.5x) and range extensions with 10x magnification in a combination objective-special eyepieces (Bel Engineering) coupled to a digital camera generating bitmap images, with 1260x960 resolution. Droplet diameter was measured, in $\mathrm{mm}$, with the function line of the software Iscapture 2.2.1 (Scienon Technology Co. Ltda) which comes together with the camera used to capture the images. The program was calibrated with an image of a ruler of $0.01 \mu \mathrm{m}$ in the same objective and zoom lens used in image capture.

Images were captured on the top view of the drop, right after droplets were deposited on the surfaces, at intervals of three seconds until the total evaporation of the droplet liquid, leaving only the solution solids on the surface. Wetting area $\left(\mathrm{mm}^{2}\right)$ was determined delimiting the drop ends by the polygon function, considering the maximum area of each replicate. Evaporation time was measured through the interval between droplet deposition and extinction of the liquid part, recorded by the sequential images captured during evaporation. Thus, evaporation time was calculated using number of photos multiplied by the interval between photos, according to the methodology developed by Zhu et al. (2008).

Normality of data was verified using Shapiro-Wilk test $(\mathrm{p}<0.05)$ and homogeneity of variances using Levene's test, Cochran's test and Hartley's test, and then the authors performed the analysis of variance using $\mathrm{F}$ test. The interaction of the solution and contact surfaces were observed and surface averages were compared using Tukey test $(\mathrm{P}<0.05)$; solutions were compared using Student's $t$ test $(\mathrm{P}<0.05)$.

\section{RESULTS AND DISCUSSION}

Significant interaction between deposition surface and spray solution for wetting area and droplet evaporation time was noticed. This fact indicates that spreading process and droplet evaporation are determined both by physical and chemical properties of the spray solution and by the deposition surface characteristics of the sprayed droplets, also discussed by Oliveira et al. (2015) in studies with herbicides on weeds.

Surface tension and droplet wetting on different application surfaces are represented in Figure 1. Spray solution and target surface are determinant in spreading and droplet evaporation after deposition, showing a negative relation between surface tension and spreading. Addition of adjuvant Nimbus ${ }^{\circledR}$ reduces surface tension and provides an increase in surface wetting area, with exception on tomato leaves which presented lower capacity of leaf wetness in both syrups.

Surface tension is one of the 


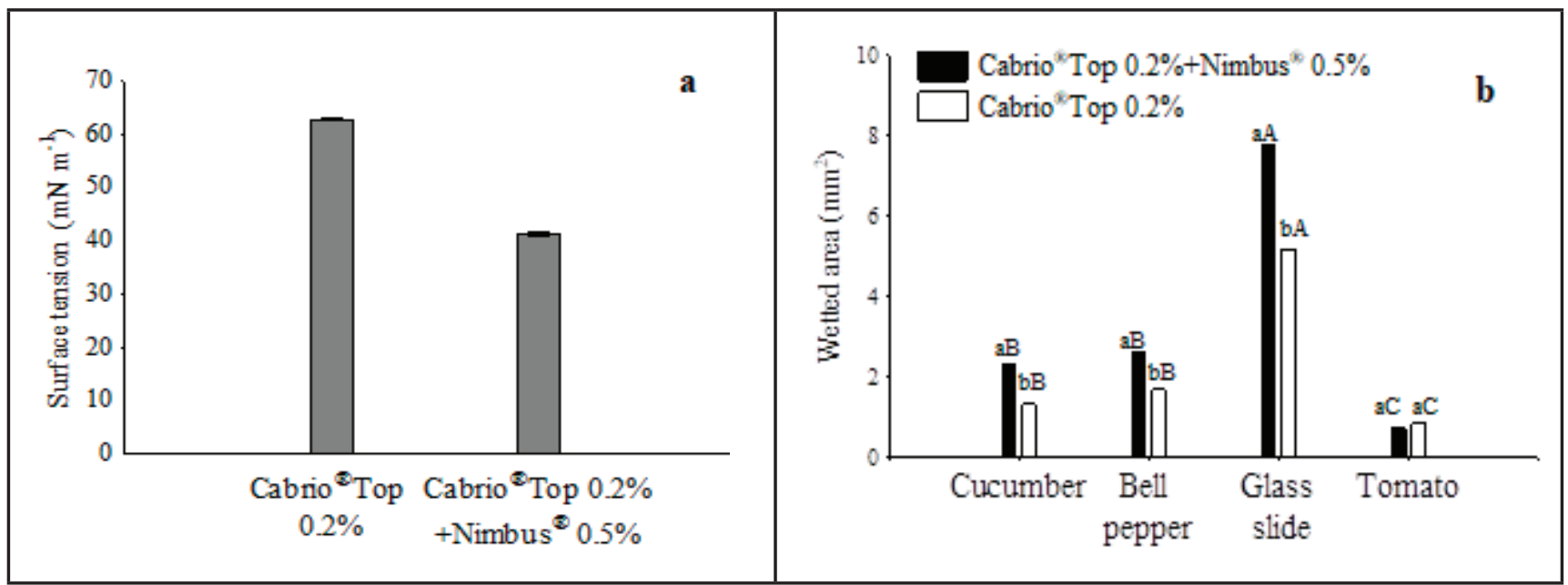

Figure 1. Surface tension (a) and wetted area (b) of spray droplets on different application surfaces. Averages followed by the same capital letters for surface do not differ significantly from each other by Tukey test $(\mathrm{p}<0.05)$ and lowercase letters for spraying solution do not differ significantly from each other by Student's t test $(\mathrm{p}<0.05)$. Bandeirantes, UENP, 2017.

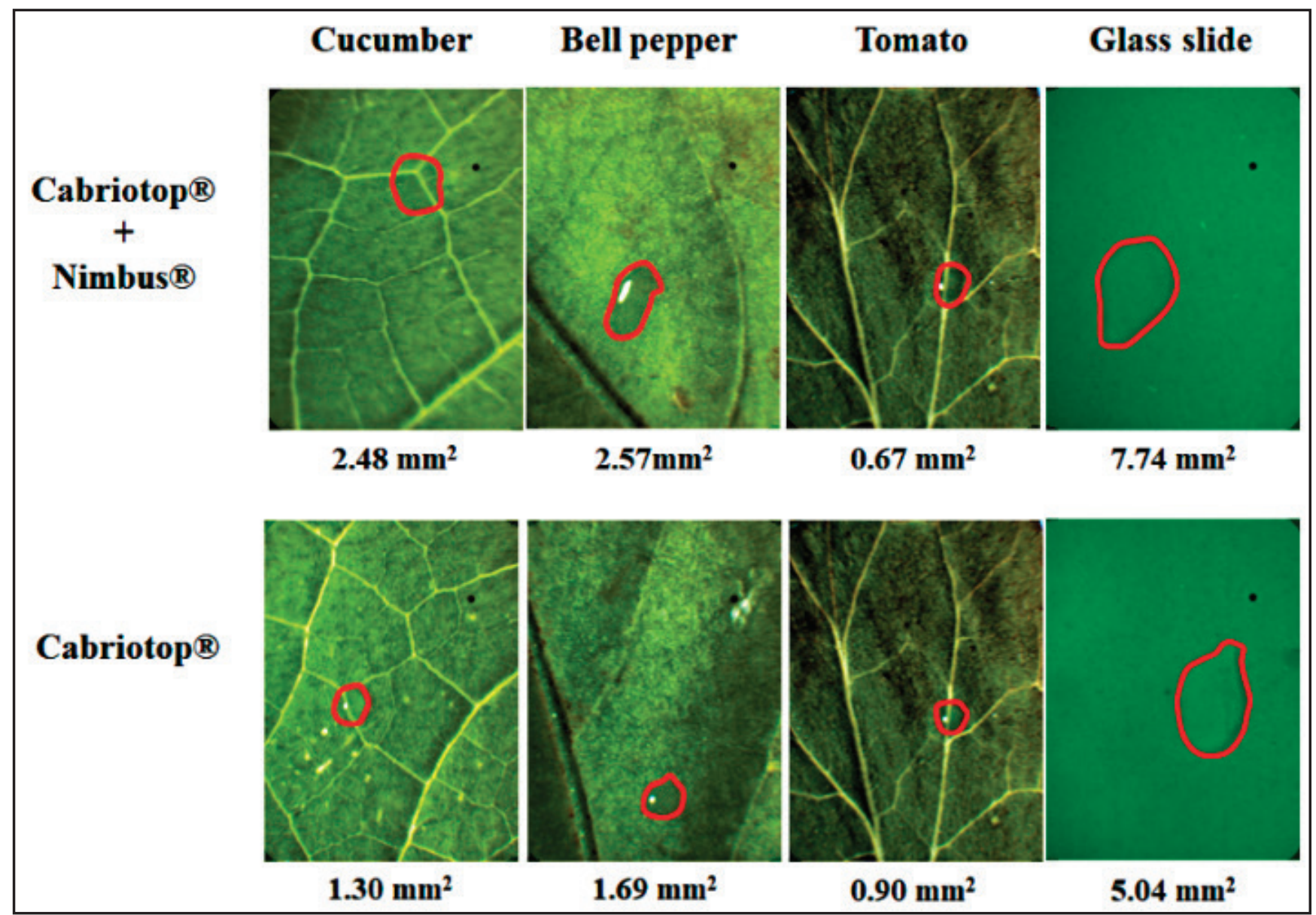

Figure 2. Maximum wetting area of droplets of $600 \mu \mathrm{m}$ in diameter $\left(\mathrm{mm}^{2}\right)$ containing spray solution deposited on four target surfaces, at $30^{\circ} \mathrm{C}$ temperature and $60 \%$ relative humidity. Bandeirantes, UENP, 2017.

mechanisms which determine droplet spreading on the target; however, this mechanism cannot be used alone in order to evaluate wetting capacity of a plant protection product, since spreading is also influenced by droplet deposition surface (Oliveira et al., 2015). This can explain the exception on the tomato leaf surface which represented greater resistance to drop spreading and did not show the same relation between the surface tension and wetting area as on other surfaces. Costa et al. (2014) also could not establish a direct relation between the surface 
tension reduction and droplet wetting increase of solutions formulated with herbicides and adjuvants applied on Conyza canadenses surfaces. Thus, in order to obtain a correct interpretation of the droplet behavior onto the target, the authors suggest the use of methods to evaluate directly spreading of droplets of solutions used for spraying.

For both spray solutions, the tomato leaf surface showed smaller wetting area in relation to other surfaces (Figure 1b), possibly related to its leaf characteristics. Tomato leaf surface shows nonglandular trichomes which could be a barrier to spreading. The authors also observe greater droplet spreading on glass surface of both solutions (Figure $2)$. These differences between natural targets and glass slides are related to the fact that slides are hydrophilic, which facilitates droplet spreading, reducing the effect of morphological variability factors which leaf surfaces present. Morphological diversity between plant species, just like trichomes, cuticle, ribs and waxes, may exert great influence on spreading of sprayed droplet and alter solution absorption (Iost \& Raetano, 2010).

\section{Addition of adjuvant Nimbus ${ }^{\circledR}$}

increased droplet evaporation time only on the cucumber leaf surface, reduced on the tomato surface and maintained the same timing on bell pepper leaf surface and glass slide (Figure 3), showing that the adjuvant can alter droplet behavior onto the target, increasing or decreasing evaporation time, or still not producing any effect at all. Addition of adjuvant into the spray solution not always provides the expected effect, since leaf surface characteristics have great influence on spraying droplet deposition.

The longer evaporation time of the droplets deposited on the tomato leaf surface in the absence of adjuvant can be explained due to the less spreading observed in this treatment. The analysis of the sequential image of the droplets deposited on leaf surface and glass slide allows observing the longevity of spraying droplets and spreading. Observing these factors is important, since the liquid of the droplet evaporates, absorption and leaf penetration of this plant protection product are reduced and formed crystals can be removed by the wind, decreasing its efficiency (Yu et al., 2009).

Glass slide showed less droplet

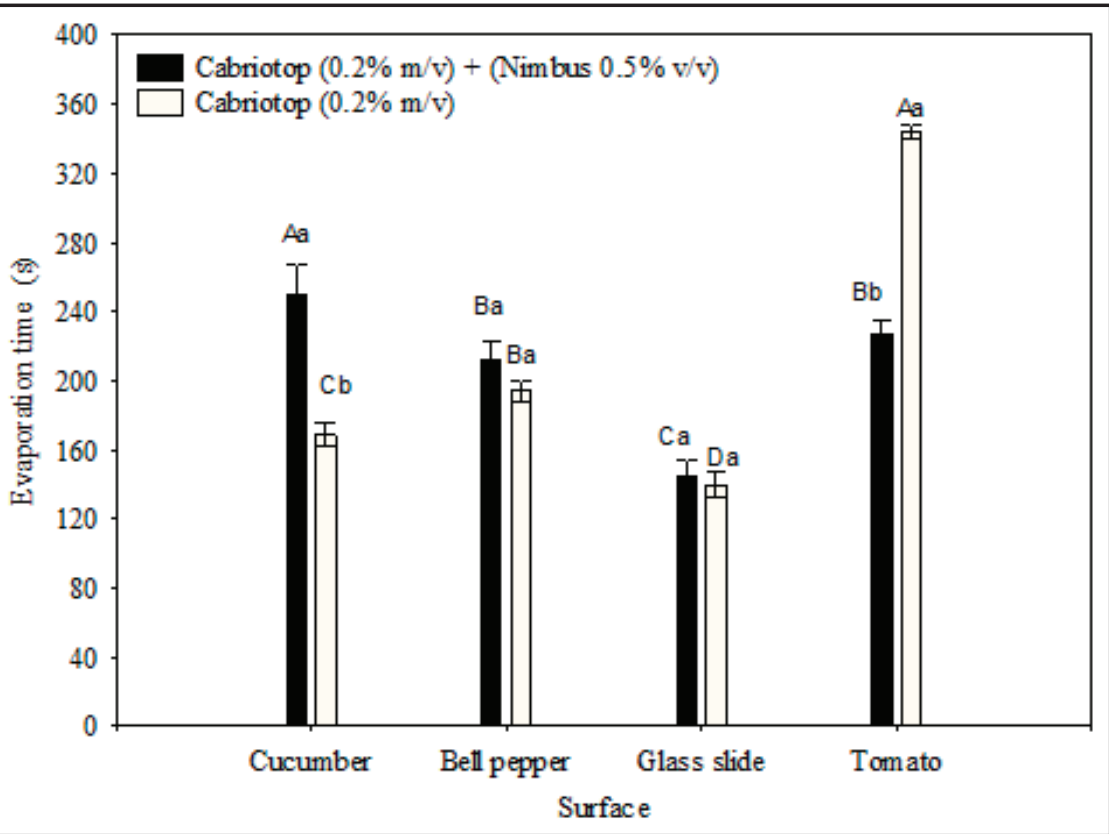

Figure 3. Evaporation time of spray droplets on different application surfaces. Averages followed by the same capital letters for surface do not differ significantly from each other by Tukey test $(\mathrm{p}<0.05)$ and lowercase letters for spraying solution do not differ significantly from each other by Student's t test $(p<0,05)$. Bandeirantes, UENP, 2017. evaporation time, in relation to leaf surfaces. This fact may have happened due to more droplet spreading on this surface, exposing the droplet to greater contact surface with the environment. Less evaporation time may be related to the difference between thermal capacity of glass slide and vegetable surfaces, considering that glass slide heats faster and, because of this, it accelerates the evaporation rate of the deposited droplets (Oliveira et al., 2015).

\section{ACKNOWLEDGEMENTS}

The first author thanks for granting to The national council for scientific and technological development (CNPq) Scientific Initiation Scholarship. To the team of Núcleo de Investigação em Tecnologia de Aplicação e Máquinas Agrícolas (NITEC) of Universidade Estadual do Norte do Paraná (UENP), Bandeirantes-PR.

\section{REFERENCES}

COSTA, NVD; MODOLON, TA; PISATTO, M; BROETTO, L; JÚNIOR, EM. 2014. Tensão superficial e área de espalhamento de gotas de soluções com herbicidas e adjuvantes em folhas de Conyza canadensis. Scientia Agraria Paranaensis 13: 161-170.

HUNSCHE, M; NOGA, G. 2012. Effects of relative humidity and substrate on the spatial association between glyphosate and ethoxylated seed oil adjuvants in the dried deposits of sessile droplets. Pesticide Management Science 68: 231-239.

IOST, CAR; RAETANO, CG. 2010.Tensão superficial dinâmica e ângulo de contato de soluções aquosas com surfactantes em superfícies artificiais e naturais. Engenharia Agrícola 30: 670-680.

MENDONÇA, CG; RAETANO, CG. 2007. Tensão superficial estática de soluções aquosas com óleos minerais e vegetais utilizados na agricultura. Engenharia Agrícola 27: 16-23.

MENDONÇA, CG; VELINI, ED; MARTINS, D. 1999. Efeitos de surfactantes sobre a tensão superficial e a área de molhamento de soluções de glyphosate sobre folhas de tiririca. PlantaDaninha 17: 355-365.

OLIVEIRA, RB; DARIO, G; ALVES, KA; GANDOLFO, MA. 2015. Influence of the glyphosate formulations on wettability and 
evaporation time of droplets on different targets. Planta daninha 33: 599-606.

XU, L; ZHU, H; OZKAN, EH. 2010. Adjuvant effects on evaporation time and wetted area of droplets on waxy leaves. Transactions of the ASABE 53: 13-20.
YU, Y; ZHU, H; OZKAN, HE; DERKSEN, RC; KRAUSE, CR. 2009. Evaporation and deposition coverage area of droplets containing insecticides and spray additives on hydrophilic, hydrophobic, and crab apple leaf surfaces. Transactions of the ASABE 52: 39-49.
ZHU, H; YU, Y; OZKAN, HE.; DERKSEN, RC; KRAUSE, CR. 2008. Influence of spray additives on droplet evaporation and residual patterns on wax and wax-free surfaces. Transactions of the ASABE No. 083752. 